\section{Arbobalans 2020}

De cijfers van Arbobalans 2020 dateren van vóór de COVID-19-pandemie. De meeste werknemers rapporteren een goede algehele gezondheid. Deze is wel ten opzichte van 2014 licht afgenomen. In 2014 zei 82\% van de werknemers dat de gezondheid goed of zeer goed is ten opzichte van 79\% in 2019. Dit wordt vooral verklaard vanuit de gestage stijging in burn-outklachten over deze periode (van 14,4\% naar 17\%). Zzp'ers hebben een betere gezondheid dan werknemers, en rapporteren veel minder burn-outklachten (8,2\%). De algehele gezondheid is het laagst onder uitzendkrachten en is tussen 2014 en 2019 ook afgenomen.

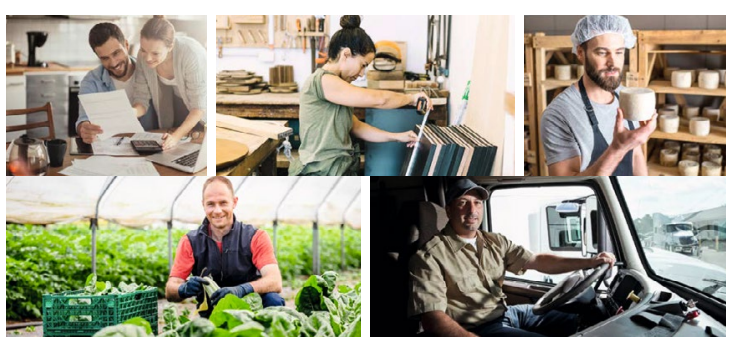

ARBOBALANS 2020

Kwaliteit van de arbeid, effecten en maatregelen in Nederland
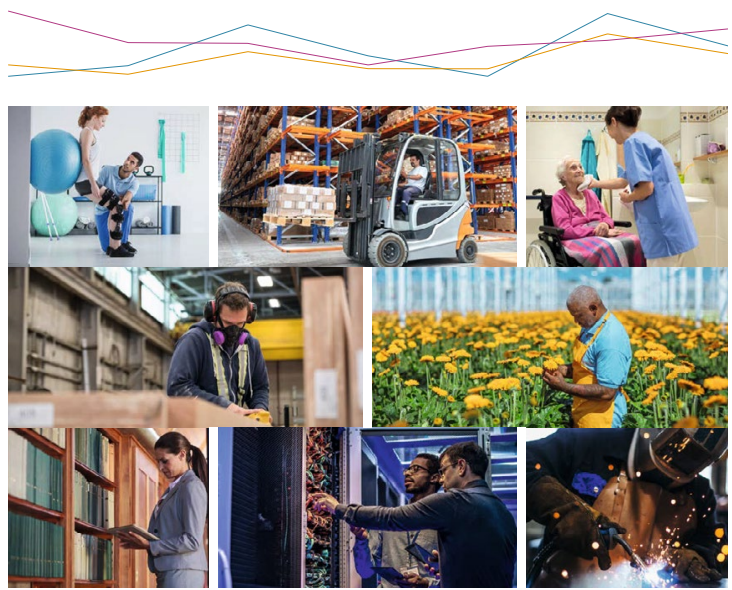

Van alle beroepsziekten is de prevalentie van psychische beroepsziekten, met name overspannenheid/burn-out, het hoogst. Bij psychische klachten, overspannenheid en burnout is de hersteltijd langer dan bij andere gezondheidsklachten. Een hoge werkdruk, lage autonomie en gepest worden op de werkvloer spelen daarbij een grote rol.

Voor recente cijfers verwijst SZW naar de TNO publicatie De impact van de Covid-19-crisis op werkenden met de stand van zaken zomer 2020. Zie https://www.monitorarbeid.tno.nl/coronacrisis/nea-covid-19

Bron: SZW 4 februari 2021
Overprikkeling bij niet-aangeboren hersenletsel Hersenletsel-Uitleg heeft onderzoeksbureau Soffos opdracht gegeven tot een onderzoek met als vraagstelling: Hoe beïnvloedt overprikkeling het leven van mensen met Niet Aangeboren Hersenletsel? Het onderzoek is gepubliceerd op https://www.hersenletsel-uitleg.nl/onderzoek-overprikkeling. In het bijzonder werd onderzocht welke invloed een zintuiglijke (over-)belasting heeft op het ontstaan en de aard van de neurologische en ook cognitieve klachten. Herstel kan maanden en soms jaren duren. Op alle fronten is participatie ernstig bemoeilijkt. De veelheid aan klachten lijkt zijn oorsprong te vinden in de oudere delen van ons zenuwstelsel zoals de hersenstam met het reticulaire netwerk, cerebellum en middenhersenen. Bron: Hersenletsel-uitleg 15 februari 2021

\section{Diabetes type 2 en leefstijl}

Tijdens de werkconferentie Preventie in het zorgstelsel op 8 februari is de samenwerking tussen Je Leefstijl Als Medicijn en Ancora Health bekendgemaakt. Bijna 1 miljoen Nederlanders kampen met diabetes type 2 . De coronapandemie laat steeds meer het belang van preventieve zorg zien. Dit geldt bij uitstek voor mensen binnen risicogroepen, zoals type 2 diabetes. Je Leefstijl Als Medicijn, een stichting gericht op het doorbreken van diabetes type 2 middels leefstijl, en Ancora Health, een tech start-up in de preventieve zorg, slaan nu de handen ineen. Een belangrijk element hierbij is het nemen van de regie over de eigen gezondheid.

Bron: Je Leefstijl Als Medicijn 9 februari 2021

Werkgever krijgt hulp en ondersteuning bij inrichten eigen teststraat

Om bedrijven praktisch te ondersteunen bij de inrichting van een eigen teststraat, hebben VNO-NCW en MKBNederland in samenwerking met het ministerie van VWS een website met toolkit en een helpdesk opgezet: werkgeverstesten.nl. Het ministerie heeft een financiële regeling in het leven geroepen om werkgevers te ondersteunen die op locatie medewerkers op corona willen laten testen door de arbodiensten of de bedrijfsarts. Het initiatief en de financiële regeling richten zich in eerste instantie alleen op bedrijven en organisaties waar thuiswerken niet mogelijk is. Het voornaamste doel is om de veiligheid op de werkvloer te vergroten. Bron: MKB Nederland, 1 februari 2021 